\section{A) Check for updates}

Cite this: Org. Biomol. Chem., 2021, 19,6746

Received 24th May 2021 Accepted 18th July 2021

DOI: 10.1039/d1ob01003d rsc.li/obc

\title{
Silicon compounds as stoichiometric coupling reagents for direct amidation
}

\author{
Joshua J. Davies, (D) D. Christopher Braddock (D) * and Paul D. Lickiss (D)*
}

Despite being one of the most frequently carried out chemical reactions in industry, there is currently no amidation protocol that is regarded as safe, high yielding, environmentally friendly and inexpensive. The direct amidation of a carboxylic acid with an amine is viewed as an inherently good solution for developing such a protocol. Since the 1960s, there has been a gradual development in the use of silicon reagents for direct amidation. This review covers the methods published to April 2021 for silicon reagent mediated direct amidation of a carboxylic acid with an amine. This review also covers the use of polymeric $\mathrm{SiO}_{2}$ to promote direct amidation.

\section{Introduction}

The ubiquity of amide bonds cannot be overestimated. ${ }^{1}$ Their key role in the function of life, along with the estimation that amide bond formation accounts for $25 \%$ of all reactions carried out in drug discovery and development, ${ }^{2}$ makes amides one of the most important functional groups known to chemists. Accordingly many efficient and inventive protocols have been developed to form this bond that have been reviewed many times..$^{3-10}$ Notwithstanding this state of affairs, it is surprising that amidation is still a reaction considered non-ideal, as outlined by the 2007 ACS Green Chemistry Institute (GCI) Pharmaceutical Roundtable, which voted that an aim to develop amide formation avoiding poor atom economy reagents should be the top priority for the chemical research community. ${ }^{11}$ In 2018, the ACS GCI Pharmaceutical Roundtable redefined the goal to develop general methods for catalytic/sustainable (direct) amide or peptide formation, reflecting the unsolved nature of sustainable amidation. ${ }^{12}$ Accordingly, much current interest is directed at the development of direct amidations of carboxylic acids with amines. ${ }^{13-17}$

A further challenge to amidation, other than the environmental impact, is scope, where the ease of direct amidation between various carboxylic acids and amines varies considerably. Ideally, a given amidation protocol, whether catalytic or stoichiometric, should be applicable to couple a wide variety of acid and amine substrates.

Over the past 50 years, various silicon reagents have been reported for direct amidations. This review summarises these

Department of Chemistry, Imperial College London, Molecular Sciences Research Hub, White City Campus, London W12 oBZ, UK. E-mail: c.braddock@imperial.ac.uk, p.lickiss@imperial.ac.uk protocols in terms of scope - including peptide bond formation. Heterogenous silicon protocols utilizing silica as a catalyst for direct amidation, are also described. The coupling reagents are grouped according to the leaving group at silicon, starting with those with $\mathrm{Si}-\mathrm{Cl}$ bonds as these were the first type to be developed for amidation, and progressing through those with $\mathrm{Si}-\mathrm{H}, \mathrm{Si}-\mathrm{N}$ and $\mathrm{Si}-\mathrm{O}$ bonds. In the case of $\mathrm{HSi}(\mathrm{OCH}$ $\left.\left(\mathrm{CF}_{3}\right)_{2}\right)_{3}$ with two different reactive $\mathrm{Si}-\mathrm{X}$ bonds it is grouped with the silanes on the basis of its reactivity. A table of comparison of the reagents (including hazards) is also presented in the review with the aim of being a quick referral tool for the reader.

\section{Reagents with $\mathrm{Si}-\mathrm{Cl}$ bonds}

\subsection{Tetrachlorosilane}

The first reported use of a stoichiometric silicon-based reagent (SR) for direct amidation of a carboxylic acid with an amine was in $1969 .{ }^{18}$ Chan et al. demonstrated that the use of silicon tetrachloride (SR1) as the reagent in pyridine as the solvent (and also as an acid scavenger) provided amide products (Scheme 1A). A key benefit of this protocol is that the chlorosilane SR1 is destroyed in the work-up and converted into silica, which is easily removed.

In 1971, Chan et al. attempted to expand the scope of this method by applying it to the synthesis of dipeptides. ${ }^{19}$ However, initial attempts to couple an $N$-protected amino acid directly with an amino ester failed, where the $N$-protected amino acid was completely recovered while the amino ester underwent polymerisation. Chan et al. proposed that a silylester would be the reactive intermediate and could be formed in situ by initial addition of the $\mathrm{N}$-protected amino acid followed by the addition of the amino ester, thus preventing 
A.

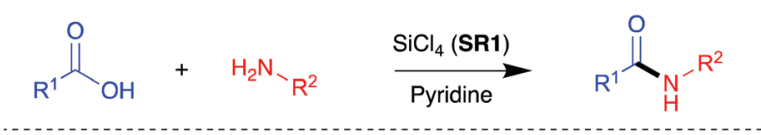

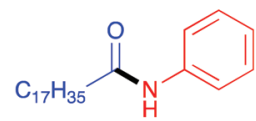<smiles>Cc1ccc(C(=O)Nc2ccccc2)cc1</smiles>

$70 \%^{a}$ $70 \%{ }^{b}$

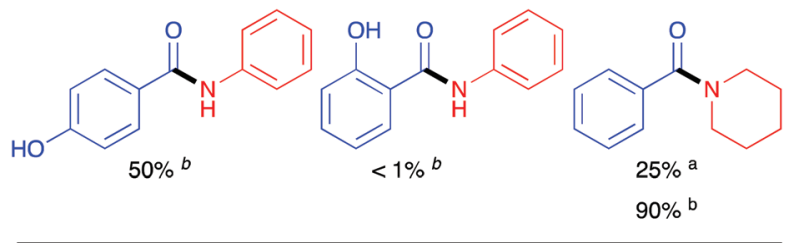

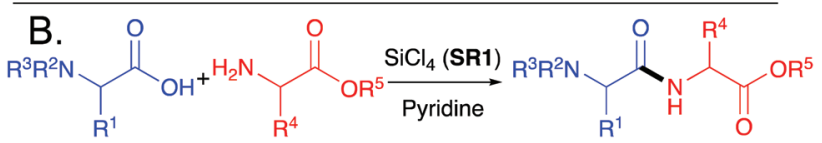

Phth-Gly-L-Leu-OMe Yield: $48 \%^{\text {a }}$

Cbz-Gly-Gly-OEt

Yield: $70 \%^{b}$
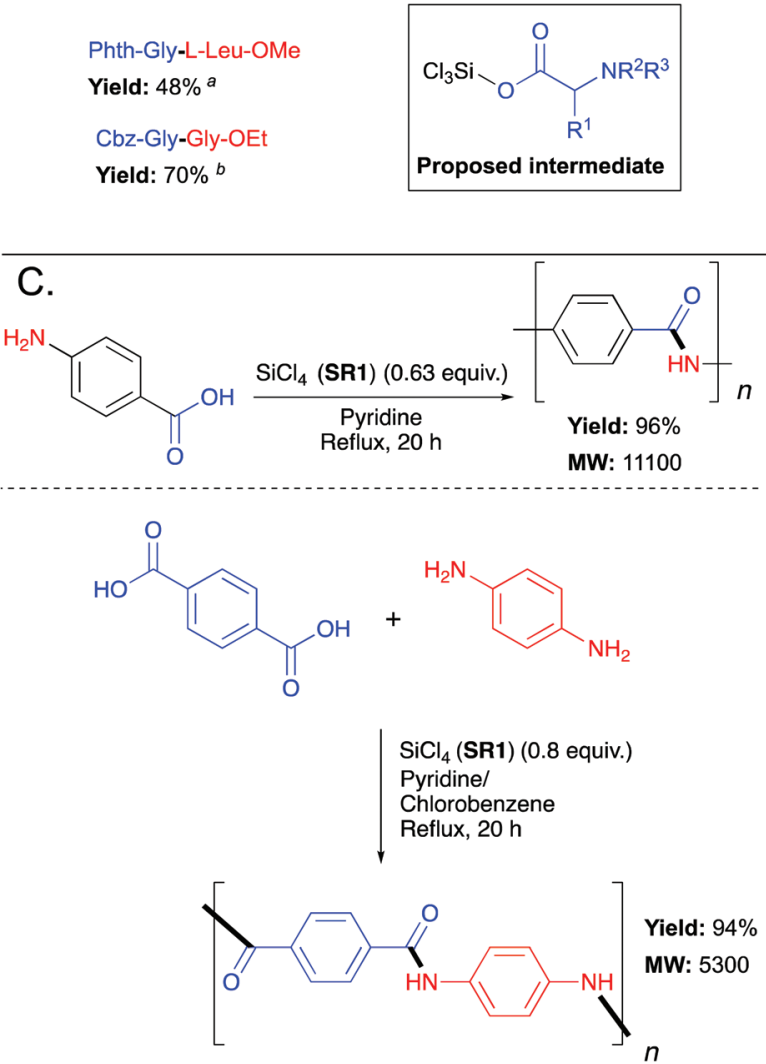

Scheme 1 (A) Selected examples of $\mathrm{SiCl}_{4}$ (SR1) mediated amide bond formation. ${ }^{18}$ Reaction conditions: ${ }^{a} 25{ }^{\circ} \mathrm{C}, 10 \mathrm{~h}$; ${ }^{b}$ reflux, $1 \mathrm{~h}$. (B) Selected examples of $\mathrm{SiCl}_{4}$ mediated formation of dipeptides. ${ }^{19}$ Reaction conditions: ${ }^{a} 110{ }^{\circ} \mathrm{C}, 30 \mathrm{~min} ;{ }^{b} 60{ }^{\circ} \mathrm{C}, 85 \mathrm{~min}$. (C) $\mathrm{SiCl}_{4}$ mediated polymerisations. ${ }^{20}$ See Table 1, entry 1 for full substrate scope.

undesirable polymerisation. Accordingly, a series of dipeptides (Scheme 1B) were made by allowing $N$-protected amino acids to react with $\mathrm{SiCl}_{4}$ prior to addition of an amino ester. ${ }^{19}$ It was noted that tetrabenzyloxy silane was a by-product with Cbz protected compounds but that other protecting groups such as phthaloyl (Phth), benzoyl (Bz) and acetyl (Ac) were tolerated. Significant racemisation was found by analysing the optical rotation of the peptide products. From the reaction of Bz-L-Leu with Gly-OEt, the optically inactive 4-isobutyl-2-phenyloxazolone was isolated and was proposed as the mode of racemisation.

In 1985, Heitz et al. showed that aromatic polyamides could be prepared via direct amidation polycondensation reactions mediated by tetrachlorosilane (SR1), and to date these constitute the only reported examples utilizing a silicon-based reagent for polyamide formation (Scheme 1C). ${ }^{20}$

\subsection{Alkylchlorosilanes}

In 2002, Leeuwen et al. demonstrated that dimethyldichlorosilane (SR2) could be utilised in a simultaneous protection-activation strategy for the direct amidation of unprotected amino acids through the presumed intermediacy of a cyclic silane (Scheme 2A). ${ }^{21}$ Pyridine was again employed as the solvent and as an acid scavenger, and the use of primary amines with the amino group attached to a primary carbon atom were required for good yield. This dichlorodialkylsilanemediated amidation strategy was also applicable to $N$-alkylamino acids, $\beta$-amino acids and also for the regioselective direct amidation of aspartic acid (Scheme 2B). In 2015 Fedorov et al. extended the scope to include $2^{\circ}$ cyclic amines as nucleophiles. ${ }^{22}$

\subsection{Arylchlorosilanes}

In 2016, Charette et al. reported conformationally flat and rigid 9-silafluorenyl dichlorides (SR5-SR10) (Scheme 2D) as superior reagents to phenyltrichlorosilane (SR4) for the direct amidation of $N$-Boc protected amino acids with amino esters (Scheme 2C). ${ }^{23}$ Notably, no epimerisation was observed in these amidations, and the method could be extended to the formation of tripeptides. A ligation mechanism is proposed. Charette $e t$ al. provided experimental evidence for the mechanism of their protocol, with a computational study being carried out by Jiang et $a l^{24}$ The coupling competency of SR7 was demonstrated over range of different amino acid substrates.

\section{Reagents with $\mathrm{Si}-\mathrm{H}$ bonds}

\subsection{Phenylsilane}

In 2006, Ruan et al. were the first to demonstrate the use of $\mathrm{PhSiH}_{3}$ (SR11) as a coupling reagent for direct amide bond formation (Scheme 3A). ${ }^{25}$ This protocol was also successful for the synthesis of solid supported amides (Scheme 3B).

In 2020 Blanchet et al. re-examined the use of $\mathrm{PhSiH}_{3}$ (SR11) and confirmed its utility for the formation of amides when using acetonitrile as the reaction solvent. ${ }^{26}$ In contrast to 


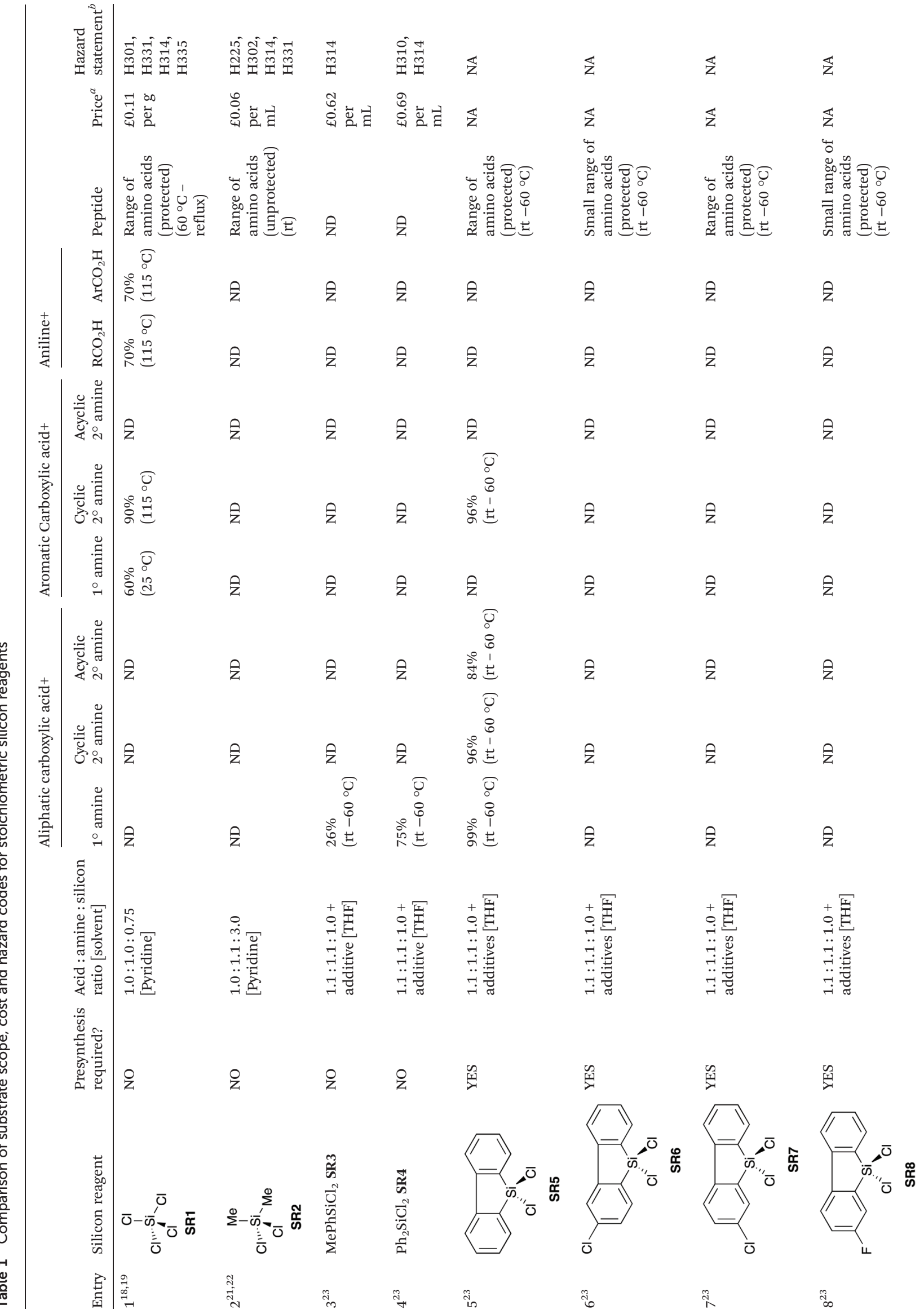




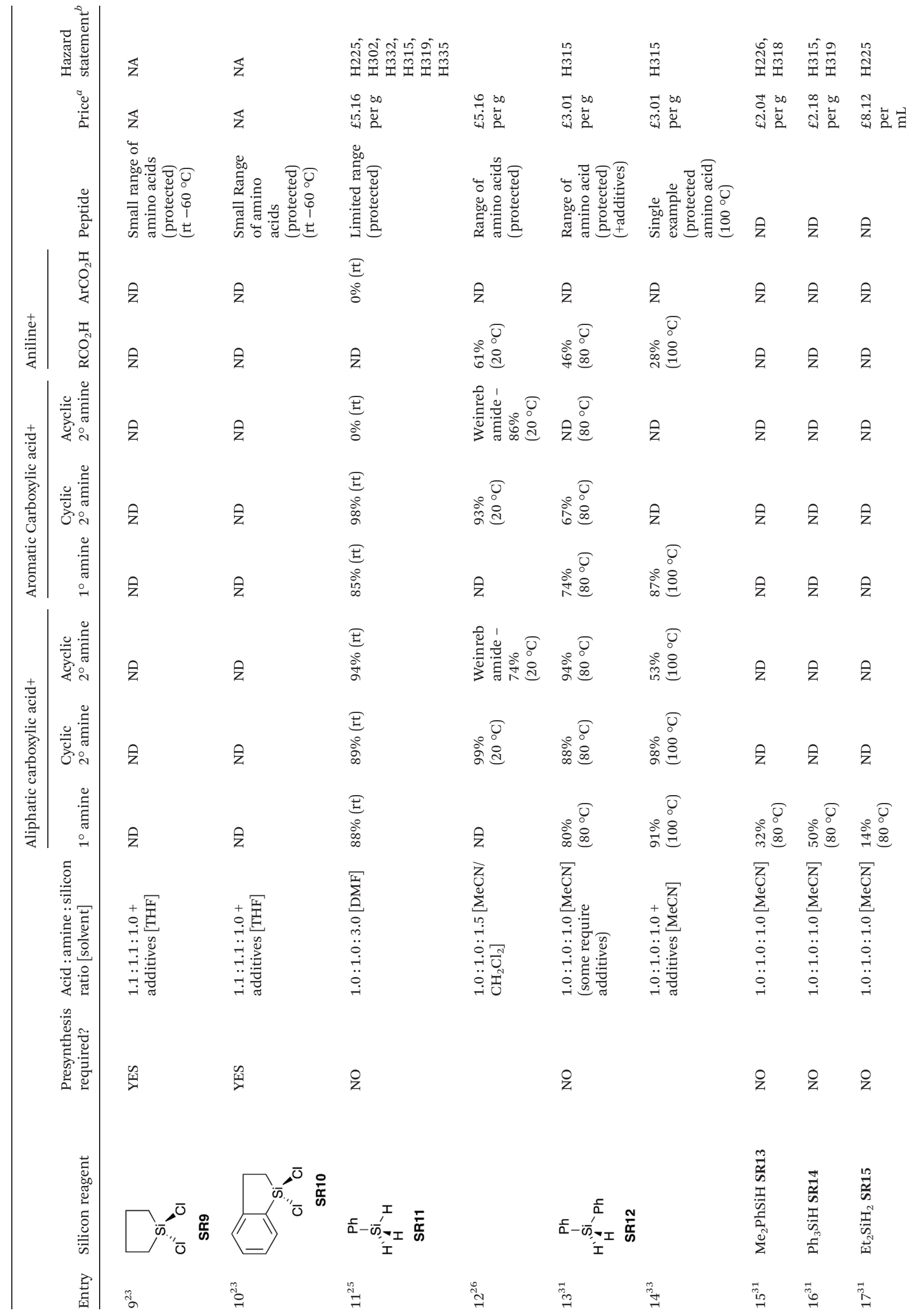




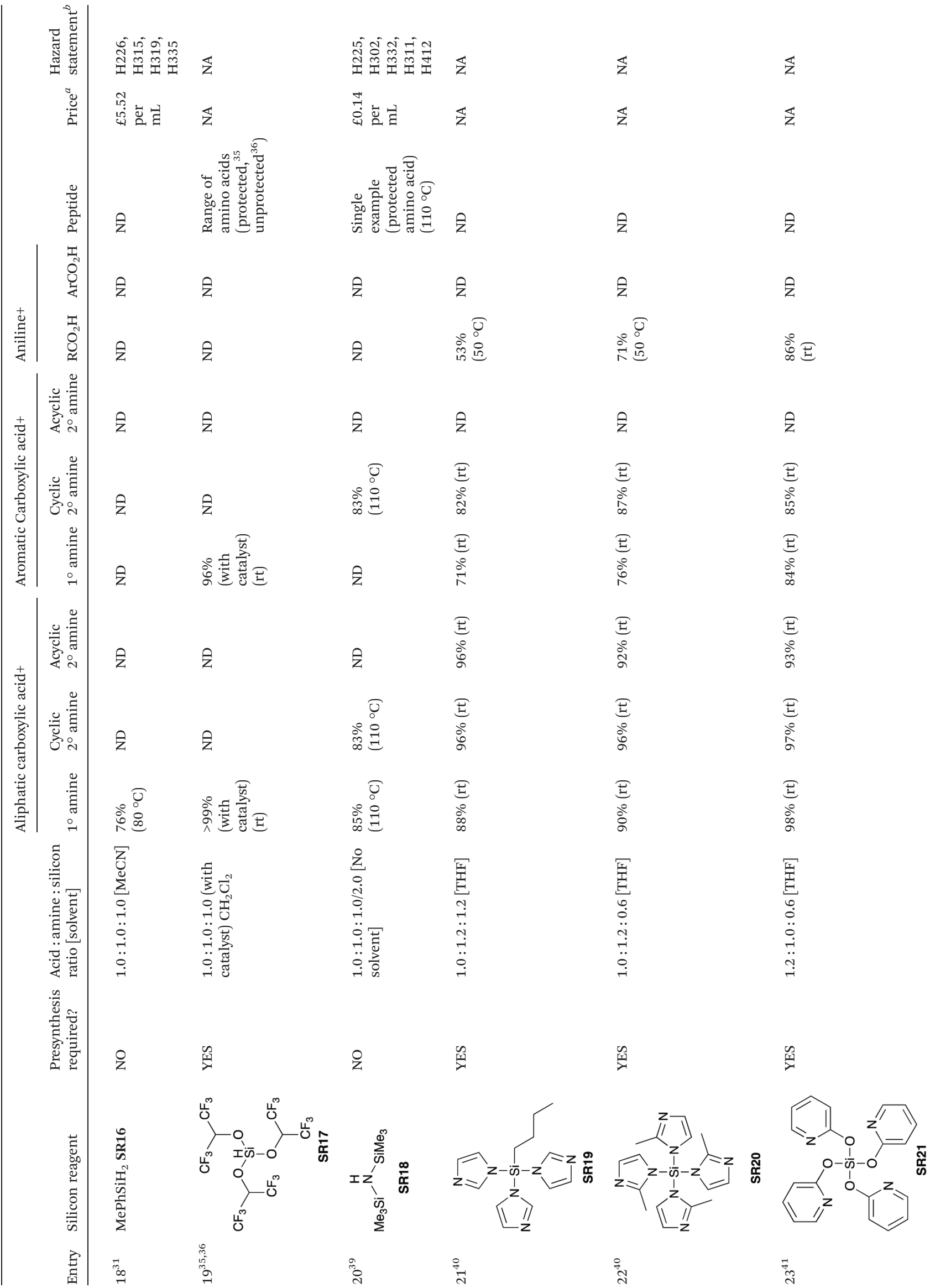




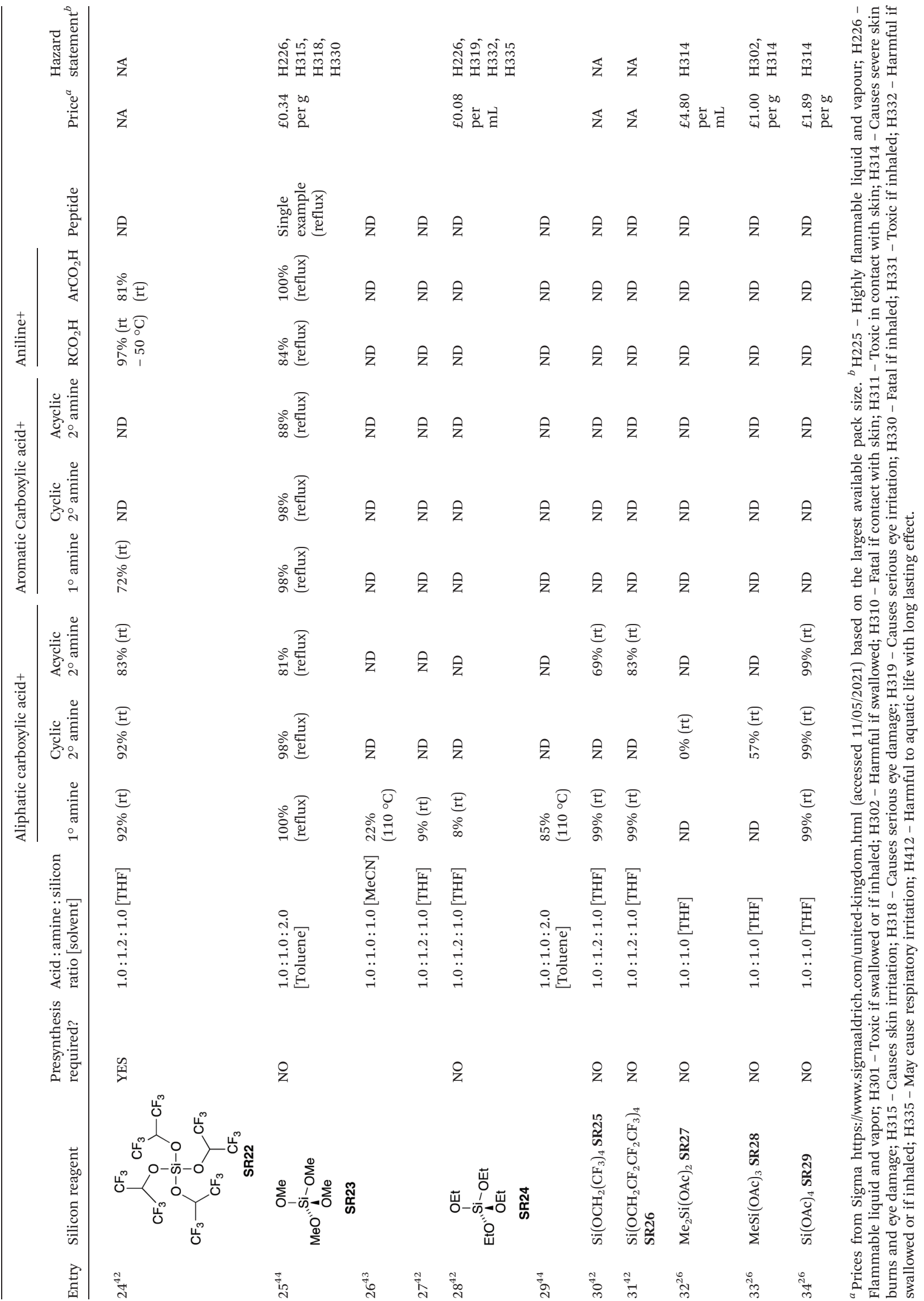


A.

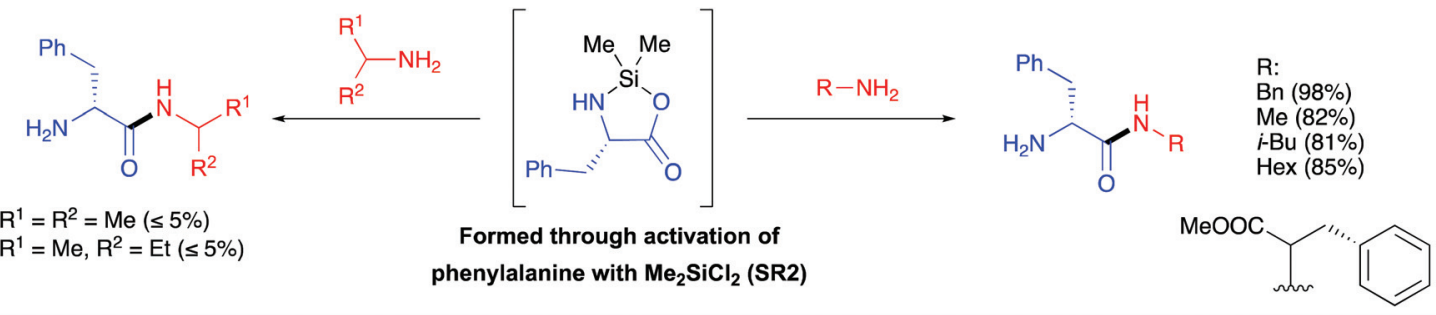

(17\%)

B.<smiles>N[C@@H](CC(=O)O)C(=O)O</smiles>

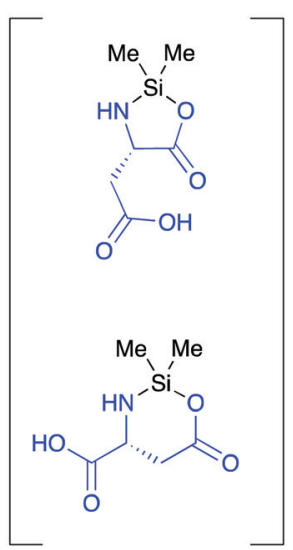

C.<smiles>O=C(O)Cc1ccccc1</smiles>

(1.1 equiv)<smiles>[CH2-][CH2-]</smiles><smiles>NCC(=O)O[Na]</smiles>

(1.1 equiv)
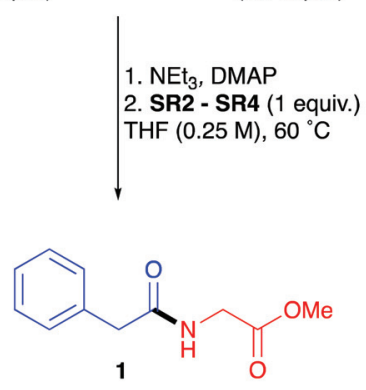

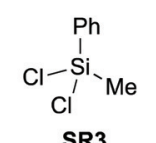

SR3

Yield $1-26 \%$ a

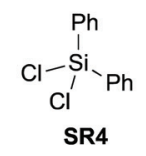

Yield $1-62^{a}$

Yield $1-75^{b}$

Yield $1-56^{c}$
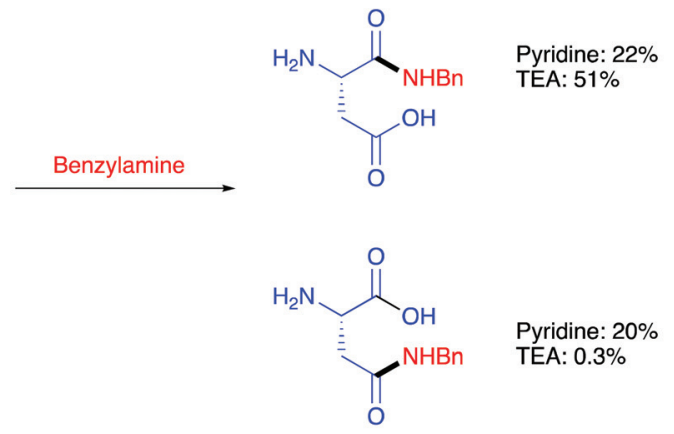

Pyridine: $20 \%$

TEA: $0.3 \%$

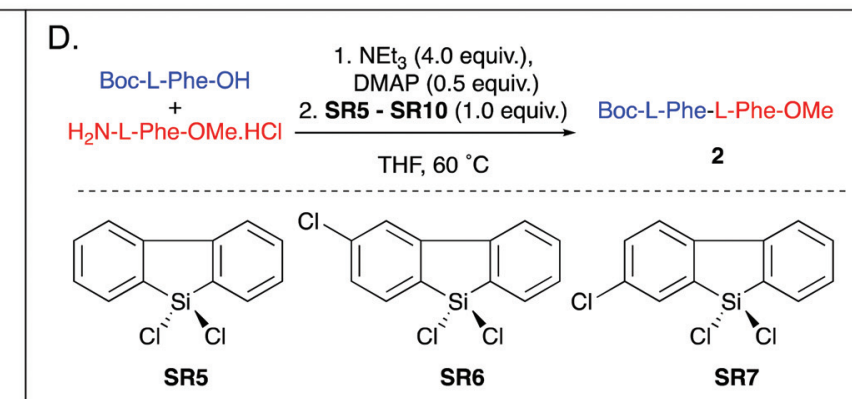

Yield 2 - 67\%

Yield 2 - 74\%

Yield 2 - $82 \%$<smiles>Fc1ccc2c(c1)[Si](Cl)([Se])c1ccccc1-2</smiles><smiles>Cl[Si]1(Cl)CCCC1</smiles>

Yield 2 - 14\%<smiles>Cl[Si]1([Hg])CCc2ccccc21</smiles>

Yield 2- 26\%

Yield 2 - 75\%

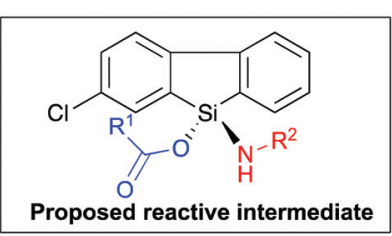

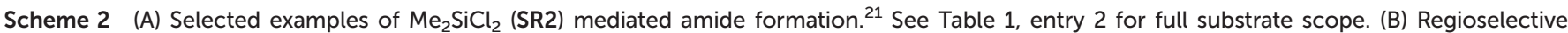

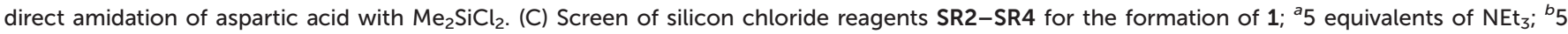

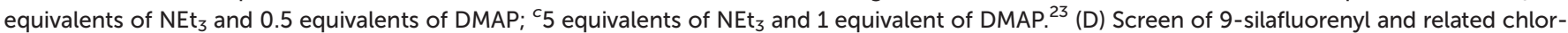
ide species SR5-SR10 for optimum amidation protocol. See Table 1, entries 5-10 for full substrate scope.

the work by Ruan et al. which employed 3 equivalents of silane SR11, it was found that the use of 1.5 equivalents of the silane was optimal.

The scope of this protocol using $\mathrm{PhSiH}_{3}$ was expanded to form Cbz-, Boc- and Fmoc-protected dipeptides and tripep- tides without any detectable epimerisation (Scheme 3C). Weinreb amide formation was also reported (Scheme 3D).

As silanes have precedent ${ }^{27}$ for the chemoselective reduction of phosphine oxides, a catalytic Staudinger ligation (Scheme 4) was developed in which phenylsilane (SR11) was 
A. 0

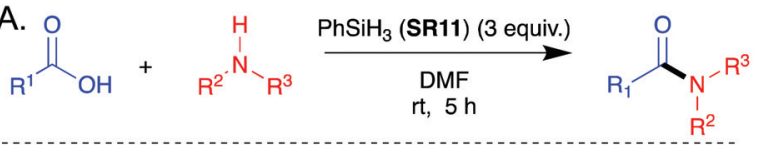<smiles>O=C(NCCCn1ccnc1)c1ccc([N+](=O)[O-])cc1</smiles><smiles>O=C(c1ccccc1)N1CCCCC1</smiles><smiles>CCCN(CC1CC1)C(=O)c1ccccc1</smiles>

$95 \%$

$98 \%$

$0 \%$<smiles>CCN(CC)C(=O)/C=C/c1ccccc1</smiles><smiles>O=C(CO)NCC(=O)OCCCCCCO</smiles><smiles>O=C(N[PH2+]c1ccccc1)c1ccccc1</smiles>

$94 \%$

$70 \%$

$0 \%$
B.<smiles>COc1ccc(CN(Cc2ccc(C(=O)O)cc2)C(=O)c2ccccc2)c(OC)c1</smiles>

1) 10 equiv. $\mathrm{R}^{1} \mathrm{NHR}^{2}$ 20 equiv. $\mathrm{PhSiH}_{3}$ (SR11) DMF, rt, $15 \mathrm{~h}$

2) $50 \%$ TFA in $\mathrm{CH}_{2} \mathrm{Cl}_{2}$, $2 \mathrm{~h}$<smiles>[H][Y]NC(=O)c1ccc(CNC(=O)P)cc1</smiles>

C.

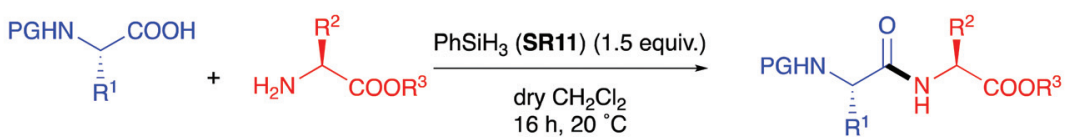<smiles>CC(=O)OC(Cc1ccccc1)NC(=O)C(Cc1ccccc1)NC(=O)OCc1ccccc1</smiles>

$80 \%$<smiles>CC(=O)OCCN1CCCC1C(=O)NCc1ccccc1</smiles>

$73 \%$<smiles>CC(=O)OC(NC(=O)[C@H](Cc1ccccc1)NC(=O)c1ccccc1)C(C)C</smiles>

$84 \%$<smiles>CC(=O)C(Cc1ccccc1)NC(=O)[C]1CCCN1Cc1ccccc1</smiles>

$73 \%$<smiles>CC(=O)NCC(=O)NCC(=O)NC(Cc1ccccc1)C(=O)NCC(=O)NC(C(C)C)C(NC(=O)c1ccccc1)C(C)C</smiles>

$55 \%$<smiles>CC(=O)CC(NC(=O)C1CCCN1C(=O)CNC(=O)c1ccccc1)C(C)=O</smiles>

$48 \%$<smiles>CC(=O)CC(OC(C)=O)C(=O)NC(Cc1c[nH]c2ccccc12)C(=O)O</smiles>

$83 \%$

D.

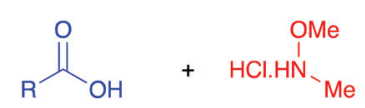

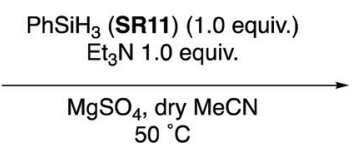<smiles>[O-][N+]([O-])[O-]</smiles><smiles>CON(C)C(=O)CNC(=O)c1ccccc1</smiles>

$74 \%$ (2h)<smiles>CON(C)C(=O)Cc1cccs1</smiles>

$47 \%$ (4h)<smiles>CN(C)C(=O)c1ccc(C(F)(F)F)cc1</smiles>

$60 \%(4 h)$<smiles>COc1ccccc1C(=O)N(C)C</smiles>

$26 \%$ (2h)<smiles>CN(C)C(=O)c1ccc([N+](=O)[O-])cc1</smiles>

$86 \%(2 h)$

Scheme 3 (A) General scheme for $\mathrm{PhSiH}_{3}$ (SR11) mediated amide bond formation and selected examples showing the scope of the reaction. ${ }^{25}$ (B) $\mathrm{PhSiH}_{3}$ mediated amidation and subsequent acid-mediated cleavage of a solid supported acid. ${ }^{25}$ (C) Selected examples showing the scope of peptide bond formation using $\mathrm{PhSiH}_{3}{ }^{26}$ (D) Formation of various Weinreb amides via $\mathrm{PhSiH}_{3}$ mediated amidation. ${ }^{26}$ See Table 1 , entries 11 and 12 for full substrate scope. 

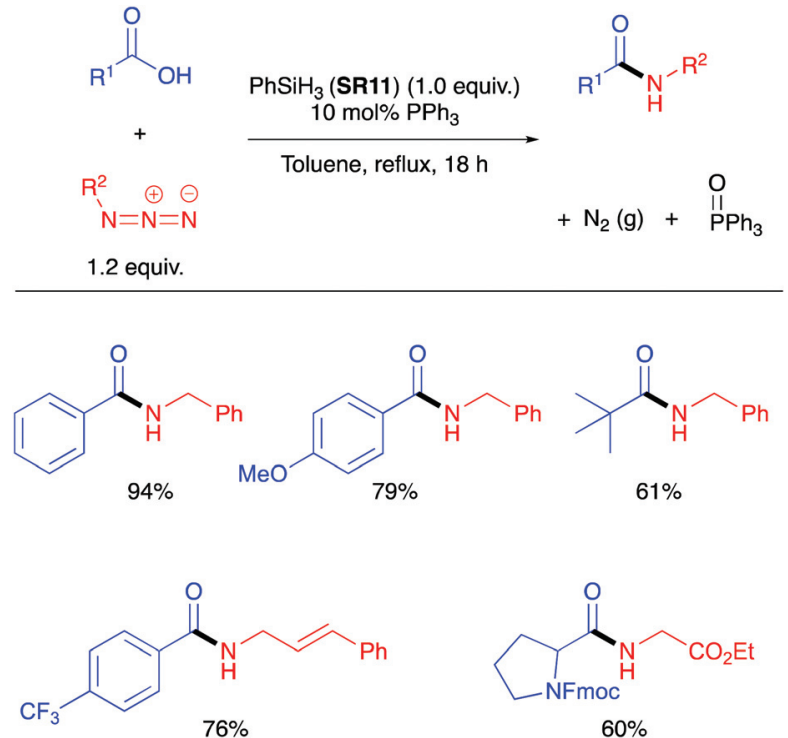

Scheme 4 Catalytic Staudinger ligation to form amides with selected examples of scope of the reaction. ${ }^{28}$

employed as the stoichiometric reductant. ${ }^{28}$ This catalytic Staudinger ligation was competent for the formation of amides, as well as lactams and peptides, notably without racemisation. Denton demonstrated that the silane cannot be simply regarded as an innocent terminal reductant in these processes, ${ }^{29}$ and subsequently White and Mecinović provided further mechanistic insight. ${ }^{30}$

\subsection{Diphenylsilane}

In 2017, Charette et al. reported the use of various aryl and alkyl silanes as reagents for direct amidation, with diphenylsilane (SR12) being the most effective under the conditions examined. ${ }^{31}$ Charette found that SR12 was a superior coupling reagent to $\mathrm{Me}_{2} \mathrm{PhSiH}$ (SR13), $\mathrm{Ph}_{3} \mathrm{SiH}$ (SR14), $\mathrm{Et}_{2} \mathrm{SiH}_{2}$ (SR15) and $\mathrm{MePhSiH}_{2}$ (SR16).

Successful direct amidation with SR12 was demonstrated for various combinations of aromatic and aliphatic carboxylic acids with primary and secondary amines (Scheme 5). Dipeptides, tripeptides and lactam of various ring sizes were also successfully formed. The stoichiometric by-products of these amidations are reported as hydrogen gas and an insoluble siloxane, which facilitates product isolation. Recent computational studies on the system suggest that these reactions proceed via nucleophilic attack of the amine on an acyloxysilane formed from the silane and the carboxylic acid with liberation of hydrogen. ${ }^{32}$ Very recently, Adler et al. have reported the beneficial effect of added $N$-methylpyrrolidine for $\mathrm{Ph}_{2} \mathrm{SiH}_{2}$ mediated direct amidations, ${ }^{33}$ as well as a Glorius robustness study for this protocol. ${ }^{34}$

\section{3. $\mathrm{HSi}\left(\mathrm{OCH}\left(\mathrm{CF}_{3}\right)_{2}\right)_{3}$}

In 2020 Muramatsu and Yamamoto published a direct amidation protocol utilizing $\mathrm{HSi}\left(\mathrm{OCH}\left(\mathrm{CF}_{3}\right)_{2}\right)_{3}$ (SR17) as a coup-

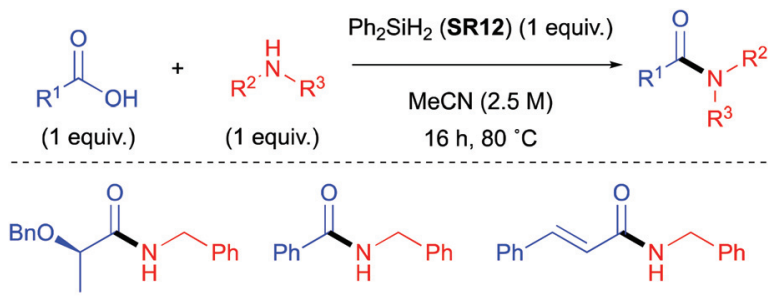

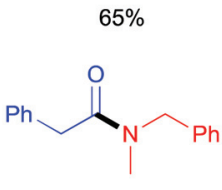

$70 \%$<smiles>O=C(O)N[C@@H]1CCNC1=O</smiles>

$78 \%$<smiles>O=C(Cc1ccccc1)N1CCOCC1</smiles>

$91 \%$<smiles>O=C(O)N[C@H]1CCCNC1=O</smiles>

$90 \%$<smiles>O=C(Cc1ccccc1)Nc1ccccc1</smiles>

$46 \%$

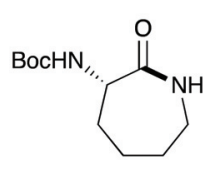

$72 \%$
Scheme 5 Selected examples of amides and lactams formed using $\mathrm{Ph}_{2} \mathrm{SiH}_{2}$ (SR12) mediated amidation. ${ }^{31}$ See Table 1, entry 13 for full substrate scope.

ling reagent ${ }^{35}$ for the epimerisation-free formation of dipeptides under ambient conditions (Scheme 6A). As for the other silanes described above, hydrogen gas and a siloxane are generated as the stoichiometric by-products. ${ }^{29} \mathrm{Si}$ NMR studies are reported to elucidate the mechanistic course of the reaction (Scheme 6B). The use of catalytic quantities of aminosilane $\mathbf{8}$ allowed the further development of a high yielding reaction protocol using the ideal $1: 1: 1$ quantities of acid:amine:reagent (Scheme 7). It is important to note that although the protocol has a catalytic aspect, a stoichiometric coupling reagent is still required to promote the bond formation.

Yamamoto et al. have since extended their protocol utilizing SR17 in combination with $N$-(tert-butyldimethylsilyl)$N$-methyltrifluoroacetamide (MTBSTFA) for the one-pot formation of dipeptides between unprotected amino acids. $^{36}$

\section{4. (EtO) $)_{2} \mathrm{MeSiH}$}

In 2014, Mecinović et al. reported the use of (EtO) ${ }_{2} \mathrm{MeSiH}$ as a stoichiometric reducing agent for $\mathrm{PPh}_{3}$ catalysed direct amidation of unactivated carboxylic acids and amines. ${ }^{37}$

\subsection{Poly(methylhydroxysilane)}

In 2017, Mecinović et al. published on poly(methylhydroxysilane) as a superstoichiometric reducing agent in an organophosphorus catalysed direct amidation between a carboxylic acid and an amine. ${ }^{38}$ A silyl ester intermediate was not detected as a reactive intermediate, and it was concluded that the silane's role is purely as a reductant. 


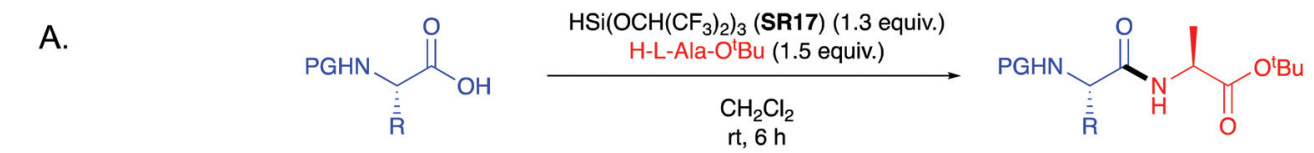<smiles>CCCCOC(=O)C(C)NC(=O)[C@H](C)NC(=O)OCc1ccccc1</smiles>

$99 \%$ yield, >99:1 er<smiles>CCCCOC(=O)C(C)NC(=O)[C@@H](C)NC(C)C</smiles>

$70 \%$ yield, $>99: 1 \mathrm{dr}$<smiles>CCCCOC(=O)C(C)NC(=O)[C@H](C)NC(F)F</smiles>

$97 \%$ yield, $>99: 1 \mathrm{dr}$<smiles>CCCCC(=O)OC(C)C(=O)N[C@@H](C)C(=O)N[13C](=O)c1ccccc1</smiles>

$97 \%$ yield, $>99: 1 \mathrm{dr}$<smiles>CCCCC(=O)OCCCCC(C)NC(=O)C(C)NC(=O)C(C)C</smiles>

$91 \%$ yield, $>99: 1 \mathrm{dr}$
B.<smiles>CC(N)C(=O)OCC(C)C(C)C(C)C(C)(C)C</smiles>

3<smiles>CCCCC(=O)C(C)NC(=O)[C@H](C)NC(=O)O</smiles>

$74 \%$ yield, $>99: 1 \mathrm{dr}$<smiles>CCCCOC(=O)C(C)NC(=O)CNC(=O)OCc1ccccc1</smiles>

$99 \%$ yield, $>99: 1 \mathrm{dr}$<smiles>CCCCC(=O)OC(C)C(NC(=O)C(C)NC(=O)OC(C)(C)C)C(C)OC(C)(C)C</smiles>

$88 \%$ yield, $>99: 1 \mathrm{dr}$

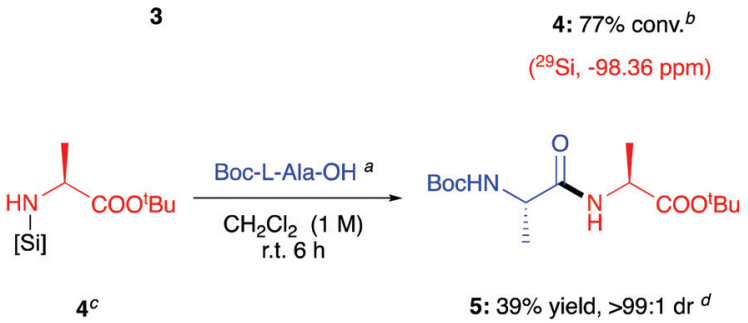

$4^{c}$<smiles>CCCCCC(=O)OC(C)N[SiH3]</smiles>

157. 4: $77 \%$ conv. $^{b}$ , $-08.36 \mathrm{ppm})$

5: 39\% yield, $>99: 1 \mathrm{dr}^{d}$<smiles>C[C@@H](NC(C)(C)C)C(=O)O</smiles>

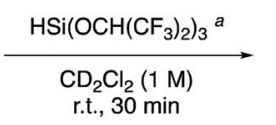<smiles>CC(C)(C)OC(=O)N[C@H](C(=O)O[Na])C(=O)O[GaH2]</smiles>

( $\left.{ }^{29} \mathrm{Si},-91.08,-94.19 \mathrm{ppm}\right)$<smiles></smiles>

$7^{e}$

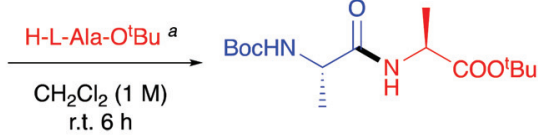

5: $89 \%$ yield, $>99: 1 \mathrm{dr}^{d}$

Scheme 6 (A) Example of scope of peptides formed with $\mathrm{HSi}\left(\mathrm{OCH}\left(\mathrm{CF}_{3}\right)_{2}\right)_{3}$ (SR17). ${ }^{35}$ See Table 1, entry 19 for full substrate scope. (B) Example of mechanistic studies carried out by Yamamoto. ${ }^{35}[\mathrm{Si}]=\mathrm{Si}\left(\mathrm{OCH}\left(\mathrm{CF}_{3}\right)_{2}\right)_{3} ;{ }^{a} 1$ equivalent added; ${ }^{b}$ conversion determined by ${ }^{1} \mathrm{H}$ NMR spectroscopy; ${ }^{{ }^{C}} 4$ was formed in situ by reaction of 3 with $\left.\mathrm{HSi}\left(\mathrm{OCH}_{(} \mathrm{CF}_{3}\right)_{2}\right)_{3}$ in $\mathrm{CH}_{2} \mathrm{Cl}_{2}$ for $1 \mathrm{~h}(\mathrm{rt}) ;{ }^{d}$ drs determined by ${ }^{1} \mathrm{H}$ NMR spectroscopy; ${ }^{{ }^{7}}$ was formed in situ by reaction of 6 with $\mathrm{HSi}\left(\mathrm{OCH}\left(\mathrm{CF}_{3}\right)_{2}\right)_{3}$ in $\mathrm{CH}_{2} \mathrm{Cl}_{2}$ for $12 \mathrm{~h}(\mathrm{rt}) .{ }^{35}$

\section{Reagents with $\mathrm{Si}-\mathrm{N}$ bonds}

\subsection{Hexamethyldisilazane}

In 1999 Chou et al. demonstrated that the use of neat HMDS (SR18) coupled carboxylic acids and piperazine (Scheme 8A). ${ }^{39}$ A base wash and subsequent chromatography resulted in pure amide products. Direct amidation of $\mathrm{N}$-Boc-Ala-OH with piperazine was also demonstrated, albeit with partial epimerisation. The intermedicacy of a silyl ester was implicated by stepwise heating of an acid with HMDS followed by addition of an amine (Scheme 8B).

\subsection{Imidazolesilanes}

In 2005, Mukaiyama et al. demonstrated that imidazole-1-ylsilanes SR19 and SR20 (Scheme 9) - prepared by trans-silylation of silylchlorides with silylimidazoles - were efficient stoichiometric coupling reagents for direct amidation at ambient temperature. ${ }^{40}$

The work-up protocol post-amidation uses hydrolysis of the silane and subsequent polycondensation to provide an in- soluble siloxane which could be readily removed by filtration and extraction with EtOAc (this is only applicable to Method B) (Scheme 10).

\section{Reagents with $\mathrm{Si}-\mathrm{O}$ bonds}

\subsection{Tetrakis(pyridine-2-yloxy)silane}

In a second report in 2005, Mukaiyama et al. demonstrated the use of tetrakis(pyridine-2-yloxy) silane (SR21) as a reagent for direct amidation to give amides in high yield at room temperature. ${ }^{41}$ The amides were delivered pure after sequential filtration, and acid-base washes (Scheme 11). As for the synthesis of imidazol-1-ylsilanes, ${ }^{40}$ tetrakis(pyridine-2-yloxy)silane (SR21) was prepared by trans-silylation.

\subsection{Tetrakis(1,1,1,3,3,3-hexafluoro-2-propoxy)silane}

In a third communication in $2005,{ }^{42}$ Mukaiyama et al. screened (Scheme 12) various alkoxy silanes for their amide 
<smiles>CCCCOC(=O)C(C)NC(=O)[C@H](C)NC(=O)OCc1ccccc1</smiles>

$98 \%$ yield $(65 \%),>99: 1 \mathrm{dr}^{b}$

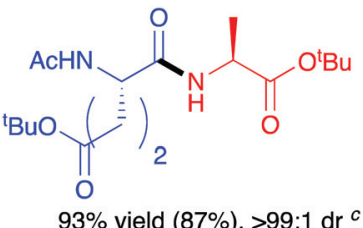<smiles>CCCOC(=O)C(C)NC(=O)CNC(=O)OCc1ccccc1</smiles>

$91 \%$ yield $(83 \%),>99: 1 \mathrm{dr}^{b}$<smiles>CCCCC(=O)C(C)NC(=O)C(NC(=O)c1ccccc1)C(C)C</smiles>

$80 \%$ yield $(69 \%),>99: 1 \mathrm{dr}^{b}$<smiles>[R]NC([R])=O</smiles>

r.t. $-40{ }^{\circ} \mathrm{C}, 6-12 \mathrm{~h}$<smiles>CCCCOC(=O)C(CNC(=O)OCC)NC(=O)[C@H](COC(C)(C)C)NC=O</smiles>

$84 \%$ yield (69\%), >99:1 $\mathrm{dr}^{c}$<smiles>CCCCOC(=O)C(C)NC(=O)[C@](C)(CC)NC(=O)OCc1ccccc1</smiles>

$43 \%$ yield $(24 \%),>99: 1 \mathrm{dr}^{c, d}$<smiles>CC(C)CNC(=O)c1ccccc1</smiles>

$96 \%$ yield $(80 \%)$

Scheme 7 Scope of dipeptides formed using Yamamoto's catalytic amidation protocol. ${ }^{35}$ Yield in parenthesis is for when aminosilane catalyst is not added. ${ }^{a}$ Silylamine formed in situ from silylation of $p$-methoxybenzylamine with $\mathrm{HSi}\left(\mathrm{OCH}\left(\mathrm{CF}_{3}\right)_{2}\right)_{3}\left(1\right.$ equiv.); ${ }^{b} \mathrm{drs}$ provided by $\mathrm{HPLC} ;{ }^{c} \mathrm{drs}$ provided by ${ }^{1} \mathrm{H}$ NMR spectroscopy; ${ }^{d} \mathrm{HSi}\left(\mathrm{OCH}_{2} \mathrm{CF}_{3}\right)_{3}$ used instead of $\mathrm{HSi}\left(\mathrm{OCH}_{(}\left(\mathrm{CF}_{3}\right)_{2}\right)_{3}$. See Table 1, entry 19 for full substrate scope.

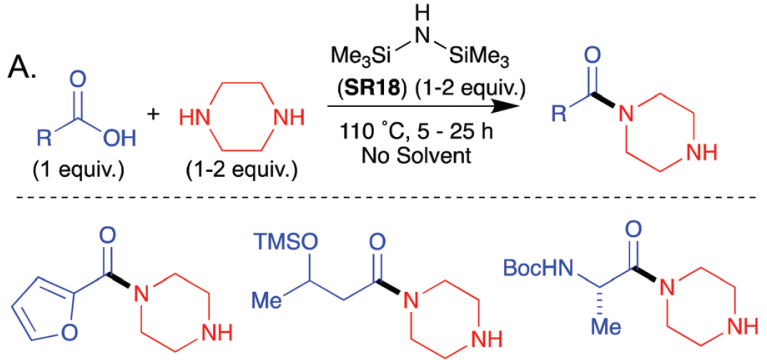

$83 \%{ }^{a}$

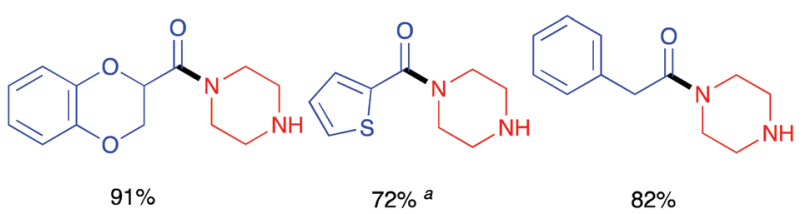

OTMs

Isolated after activation with HMDS

Scheme 8 (A) Representative scope of $\left(\mathrm{Me}_{3} \mathrm{Si}\right)_{2} \mathrm{NH}$ (SR18) mediated amidation reaction. ${ }^{39}{ }^{a} 5-9 \%$ diamide formation was observed. (B) Formation of a silylester followed by amide formation. See Table 1, entry 20 for full substrate scope.

coupling abilities, and identified tetrakis(1,1,1,3,3,3-hexafluoro-2-propoxy)silane (SR22) as the most competent coupling reagent for direct amide bond formation at room temperature.

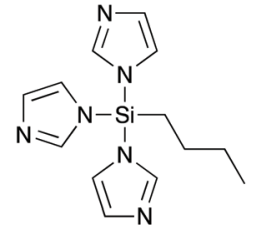

SR19

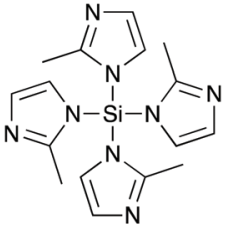

SR20
Scheme 9 Silylimidazoles prepared from trimethylsilylimidazole precursors. $^{40}$

The incorporation of fluorine substituents was found to be beneficial compared to alkoxy groups, and the branched nature of the hexafluoroisopropanol grouping prevented competitive ester formation. Pure amides were obtained after a simple acid-base wash regime. The reagent was reported to be prepared in a glove box.

\subsection{Tetramethyl orthosilicate}

Mukaiyama found that simple alkoxy silanes such as tetramethyl orthosilicate (TMOS - CAUTION: fatal if inhaled, GHS: H330 - SR23) and tetraethyl orthosilicate (TEOS - SR24) gave only low conversion when used as stoichiometric coupling reagents for amidation at room temperature in $\mathrm{THF}^{42}$ Sheppard also found that SR23 gave low conversion when used as a stoichiometric coupling reagent in refluxing acetonitrile. ${ }^{43}$ However, Braddock et al. successfully developed a TMOS based protocol in refluxing toluene to afford high yields of pure amide products from aliphatic and aromatic carboxylic acids with primary, cyclic \& acyclic secondary amines and anilines as well as other challenging amidations (Scheme 13). ${ }^{44}$ A workup procedure based on annihilation of the silicon reagent pro- 

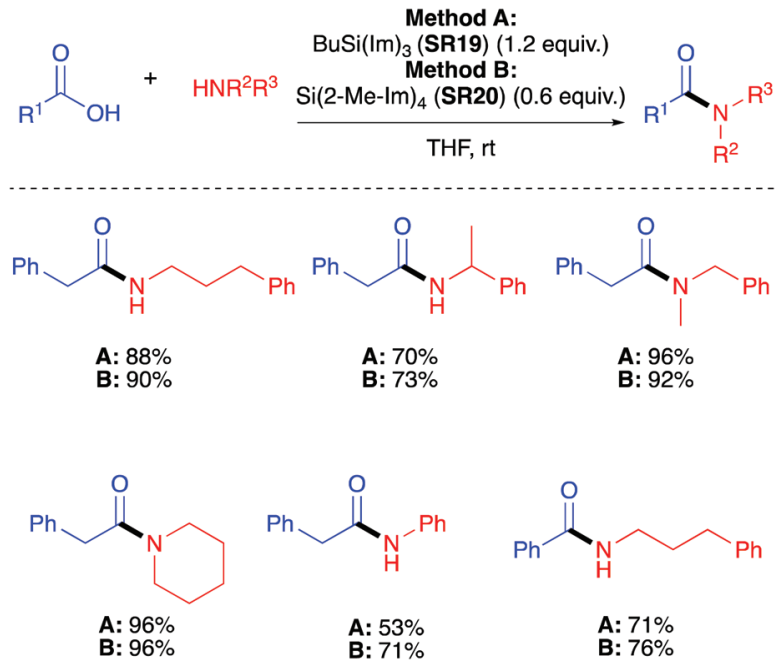

Scheme 10 Selected amide products by direct amidation using BuSi $(\mathrm{Im})_{3}\left(\right.$ SR19) and Si(2-Me-Im) ${ }_{4}\left(\right.$ SR20). ${ }^{40}$ See Table 1, entries 21 and 22 for full substrate scope.
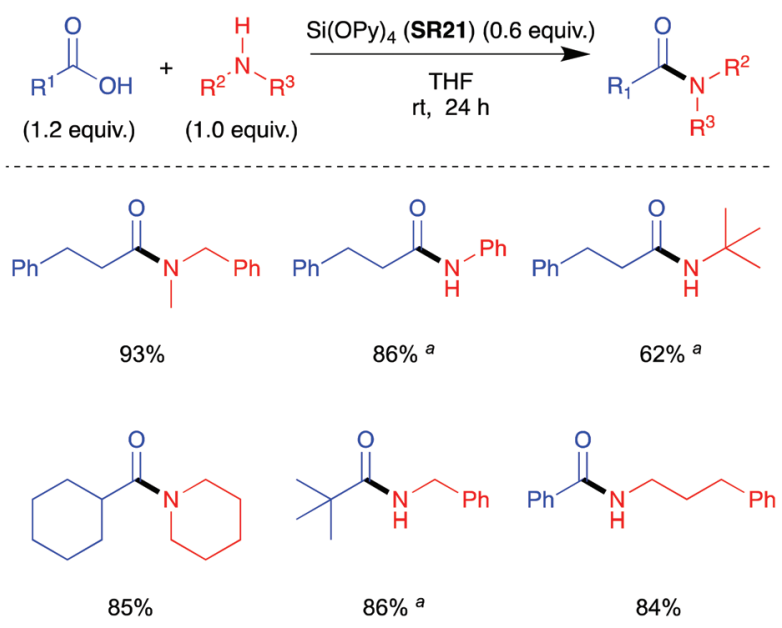

Scheme 11 Selected amide products by direct amidation using Si $(\mathrm{OPy})_{4}$ (SR21); ${ }^{a} 1.5$ equiv. of carboxylic acid was used. See Table 1, entry 23 for full substrate scope. ${ }^{41}$

vided the pure products without the need for chromatographic purification. A one mole scale amidation was demonstrated with competitive process mass intensity, and a putative reactive silyl ester intermediated was observed in situ by ${ }^{1} \mathrm{H},{ }^{13} \mathrm{C}$ and ${ }^{29}$ Si NMR methods. TMOS (SR23) has since been demonstrated successfully for the direct amidation of carboxylic acids with pentafluorosulfanyl aniline. ${ }^{45}$

\subsection{Silicon tetraacetate}

Blanchet et al. screened a series of commercially available silyl acetates: $\mathrm{Me}_{2} \mathrm{Si}(\mathrm{OAc})_{2}$ (SR27), $\operatorname{MeSi}(\mathrm{OAc})_{3} \quad$ (SR28), $\mathrm{Si}(\mathrm{OAc})_{4}$ (SR29), to determine their ability to acetylate morpholine stoichiometrically. ${ }^{26}$ The results showed that the $\mathrm{Si}(\mathrm{OAc})_{4}$ provided complete conversion to 4-acetylmorpholine after only

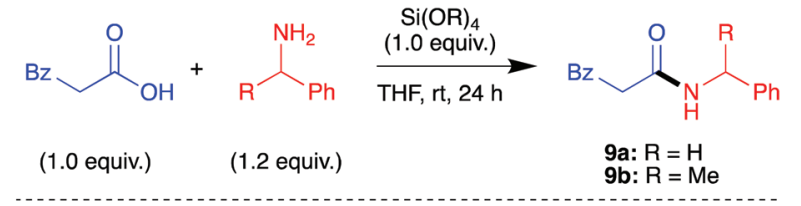

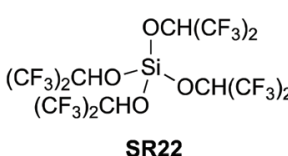

SR22

Yield 9a: 49\%

Yield 9a: $92 \%$ a

Yield 9a: $82 \%^{b}$

Yield 9b: $86 \%$

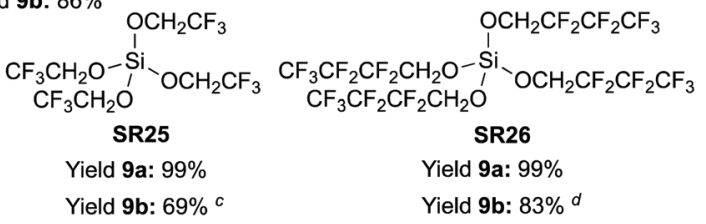

Scheme 12 Screen of various alkoxysilanes SR22-26 for amidation. ${ }^{42}$ ${ }^{a} \mathrm{Si}\left[\mathrm{OCH}\left(\mathrm{CF}_{3}\right)_{2}\right]_{4}\left(0.5\right.$ equiv.) was used; ${ }^{b} \mathrm{Si}\left[\mathrm{OCH}\left(\mathrm{CF}_{3}\right)_{2}\right]_{4}$ (0.25 equiv.) was used; ${ }^{c} 2,2,2$-Trifluoroethyl ester was afforded as by-product ( $23 \%$ yield); ${ }^{d} 2,2,3,3,4,4,4-$ Heptafluorobutyl ester was afforded as a by-product ( $8 \%$ yield). See Table 1, entries 24, 27, 28, 30 and 31 for full substrate scope.

10 minutes at $0{ }^{\circ} \mathrm{C}$ in tetrahydrofuran solvent. However, after $5 \mathrm{~h} \mathrm{MeSi}(\mathrm{OAc})_{3}$ provided only $57 \%$ yield and $\mathrm{Me}_{2} \mathrm{Si}(\mathrm{OAc})_{2}$ gave no conversion. It was found that $\mathrm{Si}(\mathrm{OAc})_{4}$ was able to acetylate a range of amines (Scheme 14). Chan had previously shown that $\mathrm{Si}(\mathrm{OAc})_{4}$ (SR29) was competent at acylating aniline when the reaction was carried out in refluxing toluene. ${ }^{19}$

\section{Heterogenous silicon reagents}

In addition to the homogenous, stoichiometric silicon reagents described above there are several reports of the use of heterogenous silicas to promote effective amidation. These studies concluded that silanol groups on the surface of silicas promote the adsorption of amine and acid substrates and enable direct amidation, often with high yields. ${ }^{46}$

Clark et al. discovered that (Kieselgel 60, K60) could be used to promote formation of a range of alkyl and aryl amides but that pre-drying of the silica at $700{ }^{\circ} \mathrm{C}$, was required (Scheme 15). ${ }^{47}$ Silica gel (K60) has also been used by Zhang et al. as an effective coupling catalyst to provide a range of different amides without requiring the pre-treatment of the silica. ${ }^{47,48}$ Gamba-Sánchez et al. applied microwaves to promote amidations without the requirement for pre-treatment of the silica. ${ }^{49}$ They found that high selectivity could be achieved with carboxylic acids providing higher yields with primary amines over cyclic secondary and aromatic amines, and also showing preference for the reaction of the amine functionality in binucleophilic substrates, such as ethanolamine. ${ }^{49}$

Other mesoporous silicas, such as the more expensive MCM-41, have been shown by Komura et al. to promote amida- 


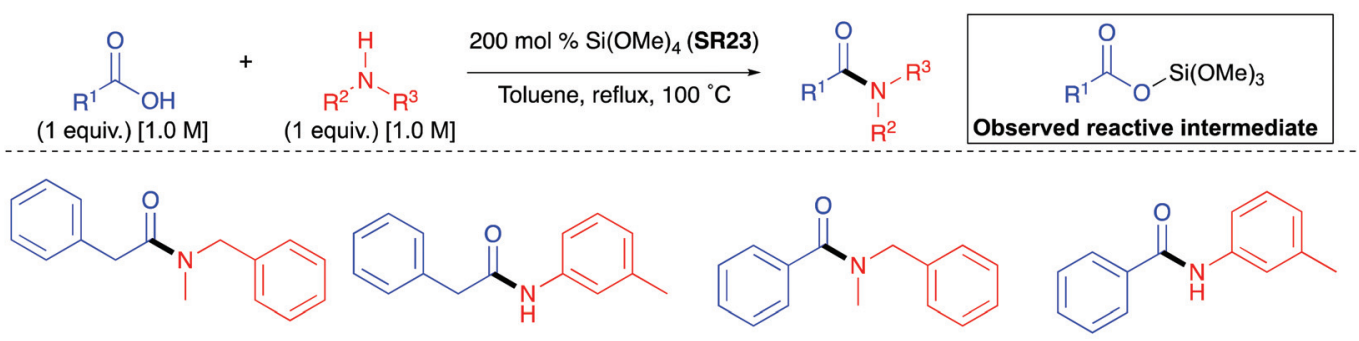

$11 \mathrm{~h}, 81 \%$

$24 \mathrm{~h}, 90 \%^{a}$

$24 \mathrm{~h}, 88 \%$

$3 \mathrm{~h}, 99 \%{ }^{b, c, d}$<smiles>O=C(NCCN1CCOCC1)c1ccc(Cl)cc1</smiles>

66 h, $87 \%$

$1 \mathrm{~h}, 100 \%$<smiles>O=C(Cc1ccccc1)Nc1ccccn1</smiles>

16 h, $53 \%$<smiles>Cc1ccc(CNC(=O)c2ccccn2)cc1</smiles>

$2 \mathrm{~h}, 84 \%$<smiles>COc1ccc2c(c1)c(CC(=O)N1CCCC1)c(C)n2C(=O)c1ccc(C)cc1</smiles>

5 h, $86 \%$

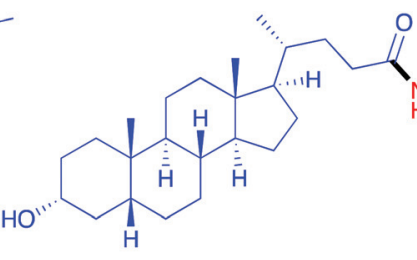

5 h, $86 \%$<smiles>CC(NC(=O)[C@H](C)NC(=O)OCc1ccccc1)c1ccccc1</smiles>

$1.5 \mathrm{~h}, 87 \%$

Scheme 13 Selected examples of amides formed via TMOS (SR23) mediated coupling. ${ }^{44}$ a $\left[\right.$ acid] $=0.5 \mathrm{M}$, [amine] $=0.5 \mathrm{M} ;{ }^{b} 250 \mathrm{~mol} \%$ TMOS, $\mathrm{N}_{2}$, [acid] $=2.0 \mathrm{M}$, [amine] $=2.0 \mathrm{M}$; ${ }^{C}$ With $4 \AA$ A molecular sieves suspended in the head space; ${ }^{d} 2$ equiv. of BzOH. See Table 1 , entry 25 for full substrate scope.

$$
\text { (SR29) }(1.0 \text { equiv.) }
$$

Scheme 14 Selected examples of amides formed by acetylation using $\mathrm{Si}(\mathrm{OAc})_{4}$ (SR29). ${ }^{26}$ See Table 1, entry 34 for full substrate scope.

tion of fatty acids and long chain amines. ${ }^{50}$ The MCM-41 promoted a greater conversion of palmitic acid and $n$-hexylamine in refluxing toluene than either the activated $^{47}$ or non-activated $^{48}$ silica, with no loss in catalytic activity when recycled. ${ }^{50}$ Komura also reported the use of mesoporous silica SBA-15 as a heterogenous catalyst. ${ }^{51}$ Work by Fontaine et al. improved the catalytic activity of SBA-15 by enriching the material with Lewis

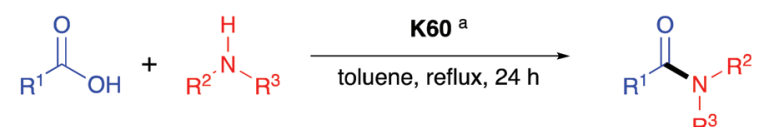
$\mathrm{R}^{3}$<smiles>O=C(Cc1ccccc1)Nc1ccccc1</smiles>

$81 \%[20 \%]$<smiles>CCCCNC(=O)c1ccccc1</smiles>

$65 \%[50 \%]$<smiles>O=C(Cc1ccccc1)N1CCCC1</smiles>

$89 \%[20 \%]$<smiles>O=C(Nc1ccccc1)c1ccccc1</smiles>

$47 \%[50 \%]$<smiles>CCCCNC(=O)CC</smiles>

$98 \%[10 \%]^{b}$<smiles>O=C(Nc1ccccc1)OCc1ccc(Cl)cc1</smiles>

$73 \%[20 \%]$
Scheme 15 Selected examples of amides formed via K60 mediated

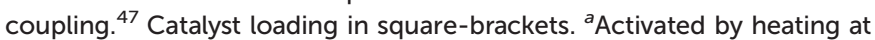
$700^{\circ} \mathrm{C}$. ${ }^{b}$ Isolated after $12 \mathrm{~h}$.

acidic metals such as Ti and $\mathrm{Zr}^{52}$ When the surface silanols of the catalyst are protected with tetramethyldisilazane (TMDS) the catalytic activity drops to $9 \%$, consistent with the silanol 
groups being required for catalytic activity. SBA-15 silica with surface aminopropyl groups was also found to act as formylating agent for a series of amines and alcohols. ${ }^{53}$ Another mesoporous silica, OSU-6, has been shown to catalyse amidation for a range of substrates when a neat mixture of acid and amine are mixed with the catalyst in a heated sealed pressure tube. $^{54}$

The (K60) silica $^{47,48}$ utilized by Clark and Zhang is significantly cheaper than OSU-6, MCM-41, and SBA-15, but the more expensive silicas do not require pre-activation.

\section{Conclusion}

It is not surprising, that considering the worldwide demand for amides, the expectations for novel reagents for direct amidation of carboxylic acids are high. A chemist developing a novel coupling reagent with the aim of industrial implementation will need to ensure that their protocol is high yielding for a wide scope of reactants, is environmentally friendly, safe to use, and commercially available and affordable. This review shows that the silicon reagents presented above are competent at promoting amide bond formation by direct amidation of carboxylic acids with varied substrate scope. However, there is still need for improvement. A combination of broad scope, safety, environmental impact and affordability has not yet been achieved by any one of the reagents presented in this review. In terms of safety, many of the compounds (TMOS, $\mathrm{SiCl}_{4}$ and $\mathrm{PhSiH}_{3}$ ) display hazard symbols that make them uninviting to the industrial chemist. Many of the protocols presented still utilize a chromatographic purification of the amide product which does not meet the demands for an environmentally friendly amidation. The beneficial properties of several of the silicon reagents that allows for the simple conversion to insoluble siloxanes and subsequent removal by filtration, or annihilation by aqueous work-up, should be pursued and exploited with the aim of reducing process mass intensities. Notably, the majority of reagents presented are commercially available making them attractive to the synthetic community. However, the search remains for a silicon-based reagent that meets all these highly demanding criteria. $^{55}$ Moreover, the advent of a silicon-based catalyst for direct amidation would be a further advance and is overdue.

\section{Conflicts of interest}

There are no conflicts to declare.

\section{Acknowledgements}

We thank the EPSRC Centre for Doctoral Training in Next Generation Synthesis and Reaction Technology (Imperial College London, EP/S023232/1) for a studentship to J. J. D.

\section{Notes and references}

1 A. Greenberg, C. M. Breneman and J. F. Liebm, The amide linkage: selected structural aspects in chemistry, biochemistry, and materials science, Wiley-Interscience, New York, 2002.

2 J. Boström, D. G. Brown, R. J. Young and G. M. Keserü, Nat. Rev. Drug Discovery, 2018, 17, 709-727.

3 E. Valeur and M. Bradley, Chem. Soc. Rev., 2009, 38, 606631.

4 V. R. Pattabiraman and J. W. Bode, Nature, 2011, 480, 471479.

5 J. R. Dunetz, J. Magano and G. A. Weisenburger, Org. Process Res. Dev., 2016, 20, 140-177.

6 A. Ojeda-Porras and D. Gamba-Sánchez, J. Org. Chem., 2016, 81, 11548-11555.

7 R. M. De Figueiredo, J. S. Suppo and J. M. Campagne, Chem. Rev., 2016, 116, 12029-12122.

8 E. Massolo, M. Pirola and M. Benaglia, Eur. J. Org. Chem., 2020, 4641-4651.

9 A. S. Santos, A. M. S. Silva and M. M. B. Marques, Eur. J. Org. Chem., 2020, 2501-2516.

10 M. Todorovic and D. M. Perrin, Pept. Sci., 2020, 112, e24210.

11 D. J. C. Constable, P. J. Dunn, J. D. Hayler, G. R. Humphrey, J. L. Leazer, R. J. Linderman, K. Lorenz, J. Manley, B. A. Pearlman, A. Wells, A. Zaks and T. Y. Zhang, Green Chem., 2007, 9, 411-420.

12 M. C. Bryan, P. J. Dunn, D. Entwistle, F. Gallou, S. G. Koenig, J. D. Hayler, M. R. Hickey, S. Hughes, M. E. Kopach, G. Moine, P. Richardson, F. Roschangar, A. Steven and F. J. Weiberth, Green Chem., 2018, 20, 50825103.

13 H. Charville, D. Jackson, G. Hodges and A. Whiting, Chem. Commun., 2010, 46, 1813-1823.

14 R. M. Lanigan and T. D. Sheppard, Eur. J. Org. Chem., 2013, 7453-7465.

15 H. Lundberg, F. Tinnis, N. Selander and H. Adolfsson, Chem. Soc. Rev., 2014, 43, 2714-2742.

16 X. Wang, Nat. Catal., 2019, 2, 98-102.

17 M. T. Sabatini, L. T. Boulton, H. F. Sneddon and T. D. Sheppard, Nat. Catal., 2019, 2, 10-17.

18 T.-H. Chan and L. T. L. Wong, J. Org. Chem., 1969, 34, 2766-2767.

19 T.-H. Chan and L. T. L. Wong, J. Org. Chem., 1971, 36, 850853.

20 P. Strohriegl, W. Heitz and G. Weber, Makromol. Chem., Rapid Commun., 1985, 6, 111-118.

21 S. H. Van Leeuwen, P. J. L. M. Quaedflieg, Q. B. Broxterman and R. M. J. Liskamp, Tetrahedron Lett., 2002, 43, 92039207.

22 A. N. Balaev, V. N. Osipov, K. A. Okhmanovich and V. E. Fedorov, Pharm. Chem. J., 2015, 49, 334-339.

23 S. J. Aspin, S. Taillemaud, P. Cyr and A. B. Charette, Angew. Chem., Int. Ed., 2016, 55, 13833-13837.

24 Y.-Y. Jiang, L. Zhu, Y. Liang, X. Man and S. Bi, J. Org. Chem., 2017, 82, 9087-9096. 
25 Z. Ruan, R. M. Lawrence and C. B. Cooper, Tetrahedron Lett., 2006, 47, 7649-7651.

26 E. Morisset, A. Chardon, J. Rouden and J. Blanchet, Eur. J. Org. Chem., 2020, 388-392.

27 K. L. Marsi, J. Org. Chem., 1974, 39, 265-267.

28 A. D. Kosal, E. E. Wilson and B. L. Ashfeld, Angew. Chem., Int. Ed., 2012, 51, 12036-12040.

29 K. G. Andrews and R. M. Denton, Chem. Commun., 2017, 53, 7982-7985.

30 P. B. White, S. J. Rijpkema, R. P. Bunschoten and J. Mecinović, Org. Lett., 2019, 21, 1011-1014.

31 M. Sayes and A. B. Charette, Green Chem., 2017, 19, 50605064.

32 B. Hu, Y.-Y. Jiang, P. Liu, R.-X. Zhang, Q. Zhang, T.-T. Liu and S. Bi, Org. Biomol. Chem., 2019, 17, 9232-9242.

33 M. C. D'Amaral, N. Jamkhou and M. J. Adler, Green Chem., 2021, 23, 288-295.

34 K. D. Collins and F. Glorius, Nat. Chem., 2013, 5, 597-601.

35 W. Muramatsu, C. Manthena, E. Nakashima and H. Yamamoto, ACS Catal., 2020, 10, 9594-9603.

36 W. Muramatsu and H. Yamamoto, J. Am. Chem. Soc., 2021, 143, 6792-6796.

37 D. C. Lenstra, F. P. J. T. Rutjes and J. Mecinović, Chem. Commun., 2014, 50, 5763.

38 D. F. J. Hamstra, D. C. Lenstra, T. J. Koenders, F. P. J. T. Rutjes and J. Mecinović, Org. Biomol. Chem., 2017, 15, 6426-6432.

39 W. C. Chou, M. C. Chou, Y. Y. Lu and S. F. Chen, Tetrahedron Lett., 1999, 40, 3419-3422.

40 T. Tozawa, Y. Yamane and T. Mukaiyama, Chem. Lett., 2005, 34, 734-735.

41 T. Tozawa, Y. Yamane and T. Mukaiyama, Chem. Lett., 2005, 34, 1334-1335.
42 T. Tozawa, Y. Yamane and T. Mukaiyama, Chem. Lett., 2005, 34, 1586-1587.

43 P. Starkov and T. D. Sheppard, Org. Biomol. Chem., 2011, 9, 1320-1323.

44 D. C. Braddock, P. D. Lickiss, B. C. Rowley, D. Pugh, T. Purnomo, G. Santhakumar and S. J. Fussell, Org. Lett., 2018, 20, 950-953.

45 H. G. Hiscocks, D. L. Yit, G. Pascali and A. T. Ung, Monatsh. Chem., 2021, 152, 449-459.

46 A. Rimola, M. Fabbiani, M. Sodupe, P. Ugliengo and G. Martra, ACS Catal., 2018, 8, 4558-4568.

47 J. W. Comerford, J. H. Clark, D. J. MacQuarrie and S. W. Breeden, Chem. Commun., 2009, 2562-2564.

48 X.-D. Yang, X.-H. Zeng, Y.-H. Zhao, X.-Q. Wang, Z.-Q. Pan, L. Li and H.-B. Zhang, J. Comb. Chem., 2010, 12, 307310.

49 A. Ojeda-Porras, A. Hernández-Santana and D. GambaSánchez, Green Chem., 2015, 17, 3157-3163.

50 K. Komura, Y. Nakano and M. Koketsu, Green Chem., 2011, 13, 828-831.

51 M. Tamura, D. Murase and K. Komura, Synthesis, 2015, 47, 769-776.

52 M. V. Zakharova, F. Kleitz and F. G. Fontaine, Dalton Trans., 2017, 46, 3864-3876.

53 R. Malakooti, S. Sobhani, N. Razavi, S. Shafiei and R. Mokhtari, Collect. Czech. Chem. Commun., 2011, 76, 1979-1990.

54 B. Nammalwar, N. P. Muddala, F. M. Watts and R. A. Bunce, Tetrahedron, 2015, 71, 9101-9111.

55 For a one-pot, two-step amidation of a carboxylic acid and amine using $\mathrm{Ph}_{3} \mathrm{SiSH}$ as a stoichiometric coupling reagent see: A. A. Lamar and L. S. Liebeskind, Tetrahedron Lett., 2015, 56, 6034-6037. 